\title{
Motivasi Orang Tua Memilih Pondok Pesantren Insan Cendekia Boarding School Payakumbuh
}

\author{
Refoyanis Sukma ${ }^{1}$, Wirdati ${ }^{2}$ \\ Jurusan Ilmu Agama Islam, Fakultas Ilmu Sosial, Universitas Negeri Padang, Indonesia ${ }^{1,2}$ \\ refoyanissukma99@gmail.com ${ }^{1}$,wirdati@fis.unp.ac.id ${ }^{2}$
}

\begin{abstract}
Abstrak
Pemilihan sekolah yang baik menjadi satu hal yang harus dipertimbangkan orang tua dalam memberikan pendidikan terbaik bagi anaknya. Apalagi saat ini orang tua khawatir dengan adanya dampak negatif dari perkembangan teknologi dan arus globalisasi. Penelitian ini bermaksud menjelaskan motivasi intrinsik dan motivasi ekstrinsik orang tua dalam memilih pondok pesantren Insan Cendekia Boarding School Payakumbuh sebagai sarana pendidikan anak. Metode penelitian yang digunakan adalah kualitatif dengan pendekatan fenomenologi. Sumber data diambil melalui wawancara dengan orang tua/wali peserta didik dan Kepala Sekolah. Untuk memperkuat data penelitian penulis juga mengambil data melalui observasi dan dokumentasi. Seluruh data wawancara dianalisis dengan cara pengumpulan, reduksi, penyajian data dan diakhiri dengan pengambilan kesimpulan. Hasil penelitian menunjukkan bahwa motivasi orang tua memilih pondok pesantren Insan Cendekia Boarding School Payakumbuh meliputi dua jenis. Pertama, motivasi intrinsik yaitu agar anak dapat menyeimbangkan ilmu umum dan agama, agar anak menjadi seorang hafidz dan hafidzah, mandiri, disiplin, dan bertakwa kepada Allah SWT serta berbakti kepada orang tua. Kedua, motivasi ekstrinsik yaitu orang tua melihat Insan Cendekia Boarding School Payakumbuh berkualitas dan bermutu berdasarkan dari sarana prasarana yang baik, lokasi sekolah yang strategis, dan kemauan anak itu sendiri.
\end{abstract}

Kata Kunci: Motivasi, orang tua, boarding school, pondok pesantren

\section{Abstract}

Choosing a good school is one thing that must be considered by parents to provide the best education for their children. Especially when they are worried about the negative impact of technological developments and the flow of globalization. This study intends to explain the intrinsic motivation and extrinsic motivation of parents choosing the Insan Cendekia Boarding School Payakumbuh as a means of children's education. The research methodology of this research was qualitative research with phenomenology approach. The data collected by interview with the student's parents and the school headmaster. In order to strengthen the data of this research, the writer also collected the data by observation and documentation. All of the data from the interview analysed by collection, reduction, presentasion, and conclusion. The results showed that there are two motivations of parents to choose the Insan Cendekia Boarding School Payakumbuh namely intrinsic and extrinsic motivation. The intrinsic motivation is to balance general knowledge and religion of the children, they becomes a hafidz and hafidzah, independent, disciplined, and pious to Allah SWT and fillial piety to parents. The extrinsic motivation of the parents is the student's parents took Insan Cendekia Boarding School Payakumbuh as a quality school with good facilities, strategic location, and student's self-willing.

Keyword: Motivation, parents, boarding school, pondok pesantren 



\section{Pendahuluan}

Anak merupakan sebuah dasar dari terbentuknya suatu lingkungan masyarakat.Pembentukan karakter yang baik bagi anak diperlukan sejak dini supayaanak memiliki karakter yang baik, dasar pemahaman agama yang kuat, serta tumbuh dan berkembang dengan baik ketika anak menginjak usia dewasa. Ibaratnya membentuk sebuah bangunan dengan pondasi yang kokoh. Sebaliknya jika anak tidak mendapatkan pendidikan yang baik maka masyarakatpun mustahil menjadi baik.

Keberadaan anak dalam keluarga memberikan tanggung jawab secara alamiah kepada orang tua, tanggung jawab ini dilandasi oleh motivasi cinta kasih. orang tua secara sadar menjalankan tugas mengasuh dan membesarkan anak hingga mampu berdiri sendiri (dewasa) secara fisik, sosial dan moral (Mahu, Abdurrahman \& Nufus, 2019: 4). Orang tua juga harus selalu berusaha untuk memenuhi kebutuhan biologis dan kebutuhan psikologis anak-anak mereka, serta merawat dan mendidik mereka (Jailani, 2014: 246). Pendidikan sebagai sebuah lembaga yang pertama bagi anak, sudah seharusnya orang tua memberikan pengarahan dan pendidikan kepada anak dengan menanamkan ajaran agama agar memiliki akhlak dan kepribadian yang baik sesuai dengan budaya yang ada di masyarakat.

Menanamkan ajaran agama, akhlakul karimah dan menjadikan anak sebagai insan yang berilmu memang tidak bisa dilakukan sendiri saja oleh orang tua. Mendidik dan mengajarkan anak-anak bukanlah tugas yang mudah apalagi bagikedua orang tua yang sibuk bekerja untuk mencukupi keperluan keluarga. Melihat kenyataan tersebut timbul motivasi pada diri orang tua untuk memilih dengan selektif lembaga pendidikan bagi anak-anak mereka. Karena pada dasarnya semua orang tua menginginkan yang terbaik untuk anaknya. Salah satu caranya yaitu dengan mengarahkan pendidikan anak agar anak tumbuh menjadi seorang anak yang baik dan menjadi kebanggaan orang tua (Marzuki \& Maskurin, 2019: 172).

Pemilihan sekolah biasanya didasari oleh beberapa motivasi tertentu. Motivasi merupakan salah satu faktor yang mendorong seseorang untuk melakukan aktivitas tertentu, sehingga motivasi biasanya diartikan sebagai faktor yang menggerakkan perilaku seseorang (Sutrisno, 2009: 109). Setiap aktivitas yang dilakukan seseorang pasti menyertakan faktor-faktor yang mendorongnya untuk melakukan aktivitas tersebut. Dapat diartikan bahwa sesuatu yang dilakukan seseorang itu adalah kebutuhan atau keinginan dirinya. Pemilihan sekolah oleh orang tua untuk anak mereka merupakan suatu tindakan yang membantu anak agar dapat mencapai tujuan tertentu yang telah direncanakan oleh orang tua.

Undang-Undang No. 20 tahun 2003 Pasal 7 ayat 1 menuliskan bahwa orang tua berhak mengikuti seleksi lembaga pendidikan dan memperoleh informasi tentang perkembangan pendidikan anaknya untuk memberikan pendidikan terbaik bagi putra dan putrinya. Pemilihansekolah atau lembaga pendidikan bagi anak oleh orang tua tentunya berdasarkan dengan adanya serangkaian proses yang melibatkan berbagai pertimbangan (Hendriani \& Nadya, 2018: 19). Pertimbangan tersebut dipengaruhi oleh keinginan orang tua terhadap anaknya yaitu keinginan supaya anak memiliki perkembangan psikis, mental dan agama yang baik dalam hidupnya (Nurniswah, 2017: $1)$. 
Keputusan orang tua untuk memilihlembaga pendidikan bagi anak biasanya didasari oleh keinginan agar anak dapat mempersiapkan diri secara memadai dalam menjalani hidup (Saputra, 2015: 2). Pada saat ini orang tua banyak melirik sekolah Islam Terpadu (Boarding School) atau pondok pesantren sebagai sarana pendidikan anak mereka. Pendidikan pesantren merupakan pendidikan Islam yang mengusahakan untuk mengantarkan para santrinya menjadi seorang yang alim dan shalih dengan menggunakan pola pendidikan perpaduan yang dilandasi keilmuan Islam (Syafe'i, 2017: 74). Pola perpaduan dalam sistem pembelajaran tersebut baik boarding school atau pondok pesantren merupakan salah satu lembaga pendidikan yang menanamkan pendidikan umum dan memperkuat pendidikan di bidang agama.

Pondok Pesantren Insan Cendekia Boarding School Payakumbuh adalah salah satu contoh alternatif sekolah yang dipilih oleh orang tua untuk menyekolahkan anak-anak mereka. pondok pesantren Insan Cendekia Boarding School Payakumbuh disingkat dengan nama ICBS Payakumbuh ini sangat diminati oleh masyarakat dewasa ini dilihat dari banyaknya peminat dari tahun ke tahun yang mendaftarkan diri ke ICBS Payakumbuh. Pada awal berdirinya ICBS Payakumbuh memiliki jumlah siswa sebanyak 47 orang, pada tahun berikutnya yaitu tahun 2011 ICBS Payakumbuh memiliki peserta didik sebanyak 82 orang. Pada 3 tahun pelajaran terakhir yaitu dari 2018/2019 sampai tahun pelajaran 2020/2021 jumlah siswa yang mendaftar dari 1061 orang menjadi 2496 orang, artinya adanya peningkatan peminat masuk ICBS Payakumbuh.

Melihat dari perkembangan pesat itu, timbul pertanyaan yang perlu dijawab yaitu apakah faktor yang mendorong orang tua memilih ICBS Payakumbuh. Penelitian ini dilakukankarena untuk melihat apa saja yang memotivasi orang tua memilih pondok pesantren Insan Cendekia Boarding School Payakumbuh dan mengetahui motivasi intrinsik dan motivasi ekstrinsik orang tua memilih pondok pesantren Insan Cendekia Boarding SchoolPayakumbuh sebagai sarana pendidikan anak.

\section{Tinjauan Pustaka}

\section{A. Pengertian Motivasi}

Istilah motivasi (Motivation) berasal dari bahasa Latin, yaitu Movere, yang artinya "menggerakkan". Motivasi adalah suatu kekuatan dalam diri manusia yang dapat dikembangkan oleh dirinya sendiri atau dapat juga dikembangkan oleh beberapa kekuatan yang berasal dari luar dirinya yang dapat mempengaruhi hasil kinerjanya (Winardi, 2001: 6). Motivasi adalah suatu faktor yang terdapat dalam diri seseorang yang mana mendorong seseorang tersebut untuk melakukan suatu aktivitas tertentu, oleh karena itu motivasi sering diartikan dengan faktor pendorong perilaku seseorang (Sutrisno, 2009: 109). Setiap aktivitas yang dilakukan seseorang tentunya mempunyai faktor-faktor yang mendorongnya melakukan aktivitas itu. Maka dapat diartikan bahwa sesuatu yang dilakukan seseorang itu adalah kebutuhan atau keinginan dirinya.

Berdasarkan pengertian motivasi di atas dapat ditarik kesimpulan bahwa motivasi merupakan kondisi dalam pribadi seseorang yang mendorongnya untuk melakukan aktivitas, atau tindakan tertentu yang dipengaruhi oleh kebutuhan dan keinginan dalam dirinya untuk mencapai sebuah tujuan. Terdapat dua sumber dorongan pada seorang 
individu, yaitu dorongan yang berasal dari dalam diri dan dorongan yang berasal dari luar diri. Oleh karena itu motivasi dibagi menjadi motivasi intrinsik dan motivasi ekstrinsik.

\section{B. Jenis-Jenis Motivasi}

Jenis motivasi yang pertama yaitu intrinsik merupakan dorongan atau kemauan yang kuat dalam diri individu. Semakin kuat motivasi dari dalam diri individu tersebut, semakin besar kemungkinan dia akan menunjukkan perilaku yang kuat untuk mencapai tujuan (Septianti \& Melia, 2019: 132).Motivasi intrinsik juga diartikan bahwa seseorang melakukan sesuatu yang tidak didasarkan pada dorongan eksternal atau faktor luar diri. Motivasi intrinsikterbentuk karena adanya keinginan alamiah yang menggugah semangat atau mendorong seseorang untuk melakukan sesuatu guna mencapai kepuasan atau tujuan.

Motivasi yang kedua yaitu ekstrinsik yang berasal dari luar diri individu, karena adanya faktor dari luar yang menyebabkan rangsangan dari luar menjadi motivasi ekstrinsik bagi individu. Motivasi eksternal dengan kata lain menyebabkan seseorang melakukan sesuatu untuk mendapatkan sesuatu yang bermanfaat baginya (Septianti \& Melia, 2019: 133).Motivasi ekstrinsik dapat membangkitkan motivasi intrinsik, sehingga diperlukan motivasi ekstrinsik untuk memperkuat pencapaian tujuan yang telah ditetapkan. Dengan kata lain, motivasi eksternal dapat mengubah keinginan seseorang yang tidak ingin melakukan sesuatu menjadi ingin melakukan sesuatu.

Berdasarkan uraian diatas dapat disimpulkan bahwa motivasi intrinsik adalah situasi dari dalam diri seseorang yang dapat mendorongnya untuk melakukan aktivitas tertentu tanpa adanya pengaruh dari luar dirinya. Sedangkan motivasi ekstrinsik adalah suatu kondisi yang dapat mendorongnya untuk melakukan aktivitas tertentu dengan adanya pengaruh dari luar diri individu.

\section{Motivasi Orang Tua}

Orang tua adalah pembimbing pribadi pertama dalam hidup anak. Awal seorang anak menerima pendidikan itu adalah dari orang tuanya. Setiap orang tua pasti berkeinginan memberikan semua yang terbaik untuk putra dan putrinya, termasuk memberikan pendidikan yang baik. Orang tua memerlukan suatu lembaga pendidikan yang akan membantu mereka mengarahkan tujuan yang telah direncanakan. Untuk mencapai sebuah tujuan, manusia memiliki kekuatan yang mampu membuat dan mendorongnya mencapai apa yang menjadi tujuannya. Kekuatan itu dikenal dengan motivasi.

Motivasi orang tua merupakan dorongan dari harapan orang tua kepada anaknya yang merupakan bagian dari proses menuju masa depan yang lebih baik (Aprianto, 2019: 5). Motivasi yang diberikan oleh orang tua merupakan salah satu bentuk dorongan, dalam hal ini adalah semangat untuk mengembangkan kemampuan anak, karena tanpa adanya dorongan maka anak tidak dapat mengetahui sampai dimana kemampuan yang dimilikinya.

\section{Pondok Pesantren Sebagai Sebuah Lembaga Pendidikan Islam}

Salah satu lembaga pendidikan Islam yang merupakan subkultur masyarakat Indonesia adalah pesantren. Pesantren adalah salah satu institusi yang unik dengan karakteristik yang sangat kuat dan mengambil peran dalam upaya-upaya mencerdaskan bangsa (Zuhriy, 2011: 288). Istilah pesantren berasal dari kata pe-“santri”-an, kata 
"santri" bermakna murid didalam bahasa Jawa. Kemudian istilah "pondok" berasal dari bahasa Arab "funduuq" yang bermakna penginapan. Khusus di Aceh, pesantren biasa disebut dengan "dayah" (Syafe'i, 2017: 64). Jadi pesantren merupakan suatu tempat para santri atau murid untuk menuntut ilmu.

Secara garis besar, pesantren dapat dibedakan menjadi tiga jenis, yaitu salafiyah (tradisional), khalafiyah (modern) dan terpadu. Pesantren yang pertama muncul adalah pesantren salafiyah atau tradisional (Zuhriy, 2011: 291). Pesantren salafiyah ini mempunyai karakteristik berupa kesederhanaan, kebersahajaan dan keikhlasan yang murni. Dengan berkembangnya ilmu pengetahuan dan teknologi, maka pesantren juga harus bisa beradaptasi dan membuka diri pada pemikiran-pemikiran baru. Akan tetapi beradaptasi dan mengadopsi pemikiran baru yang dimaksud adalah sekedar dalam hal manajemen bukan corak pesantren itu sendiri. Idealnya pesantren harus bisa mengimbangi perkembangan zaman yang semakin canggih ini dengan mempertahankan tradisi dan nilai-nilai kesalafiannya. Kekuatan pesantren dalam membentuk kepribadian santri tidak terlepas dari diterapkannya sistem boarding school. Nama lain dari boarding school adalah sekolah berasrama. Sekolah berasrama menjadi fenomena menarik dalam pendidikan Indonesia. Para peserta didik mengikuti pendidikan seperti sekolah pada umumnya dari pagi hingga siang hari, kemudian dilanjutkan dengan pendidikan agama dimalam hari. Dan dengan pola pendidikan seperti itu peserta didik dapat menyeimbangkan antara ilmu pengetahuan agama dengan ilmu pengetahuan umum.

\section{Metode Penelitian}

Metode penelitian yang digunakan adalah kualitatif dengan pendekatan fenomenologi. Metode penelitian kualitatif merupakan metode penelitian yang secara alamiah menelaah objek-objek tertentu, dan peran peneliti menjadi sarana kunci (Sugiyono, 2012: 9). Sumber data diambil melalui wawancara dengan orang tua/wali peserta didik dan Kepala Sekolah. Untuk memperkuat data penelitian penulis juga mengambil data melalui observasi dan dokumentasi. Seluruh data wawancara dianalisis dengan cara pengumpulan, reduksi, penyajian data dan diakhiri dengan pengambilan kesimpulan. Penelitian ini merupakan penelitian lapangan yang dilaksanakan di suatu lembaga, yaitu pondok pesantren Insan Cendekia Boarding School Payakumbuh.

\section{Hasil Dan Pembahasan}

\section{Profil Pondok Pesantren Insan Cendekia Boarding School Payakumbuh}

Lembaga pendidikan Pesantren Terpadu Insan Cendekia Payakumbuh yang selanjutnya disebut dengan ICBS Payakumbuh saat ini berada di tiga lokasi, pertama di Jl. R.A. Kartini, Padang Kaduduak Kelurahan Tigo Koto Diate Kecamatan Payakumbuh Utara Kota Payakumbuh, kedua berada di kelurahan Parik Muko Aia Kecamatan Lampasi Tigo Nagori Kota Payakumbuh dan lokasi yang ketiga berada di Nagari Tarantang Kecamatan Harau Kabupaten Lima Puluh Kota Sumatera Barat. didirikan sebagai lembaga pendidikan untuk pembentukan karakter para santrinya. ICBS Payakumbuh ini berdiri dilatarbelakangi oleh beberapa hal, pertama, melihat kemerosotan moral masyarakat secara luas dan khususnya generasi muda saat ini yang 
sangat jauh dari nilai-nilai keislaman. Faktor kedua, adalah karena adanya krisis lembaga pendidikan Islam berkualitas di Sumatera Barat khususnya Kota Payakumbuh, sementara wilayah ini adalah tempat belajar agama Islam yang sangat prestisius selama beberapa dekade lalu. Faktor ketiga, adalah untuk menghimpun sumber daya manusia berkualitas, untuk menjadi pelopor pembinaan generasi yang cerdas, Islami, Mandiri dan berakhlaqul karimah. Berikutnya, adalah untuk mengembalikan peran ranah minang sebagai pencetak ulama di Nusantara (Mambangkik Batang Tarandam).

ICBS Payakumbuh didirikan pada tahun 2010 dibawah naungan Yayasan Insan Cendekia Payakumbuh. Pada tahun tersebut, Pesantren ini mulai menerima santri dengan modal sarana dan prasarana yang dimiliki berupa 3 ruang kelas, 2 ruang asrama, 1 ruang kantor dan guru, 1 unit masjid, dan 4 ruang MCK.Dengan bermodalkan kesederhanaanserta usaha-usaha maksimal yang dilakukan oleh seluruh civitas akademika, Alhamdulillah ICBS Payakumbuh mendapat perhatian dari masyarakat setempat. Terbukti dari adanya dukungan dari para tokoh masyarakat, serta mempercayakan pendidikan putra-putrinya di Pesantren Terpadu Insan Cendekia.Pada awal berdirinya ICBS Payakumbuh memiliki jumlah siswa sebanyak 47 orang dengan 27 orang laki-laki dan 20 orang perempuan. Tahun berikutnya yaitu tahun 2011 ICBS Payakumbuh memiliki peserta didik sebanyak 82 orang dengan 44 orang laki-laki dan 38 orang perempuan. Setiap tahunnya jumlah peserta didik ICBS Payakumbuh terus bertambah dan berikut data penerimaan peserta didik baru Insan Cendekia Boarding SchoolPayakumbuh beberapa tahun terakhir.

Tabel. 1

\section{Data Penerimaan Peserta Didik Baru Insan Cnedekia Boarding School} Payakumbuh

\begin{tabular}{crcc}
\multirow{2}{*}{ No. } & Tahun Pelajaran & \multicolumn{2}{c}{ Jumlah Siswa } \\
\cline { 3 - 4 } & & Yang Mendaftar & Yang Diterima \\
$\mathbf{n}$ & $2018 / 2019$ & 1061 & 756 \\
$\mathbf{2}$ & $2019 / 2020$ & 1333 & 835 \\
$\mathbf{3}$ & $2020 / 2021$ & 2496 & 1050 \\
JUMLAH & 4890 & 2641 \\
\hline
\end{tabular}

Sumber: Dokumentasi Tata Usaha ICBS Payakumbuh 2021

Setiap lembaga pendidikan tentunya memiliki Visi dan Misi untuk menjadikan lembaga tersebut menjadi lebih baik. Termasuk juga pondok pesantren Insan Cendekia Boarding SchoolPayakumbuh. Adapun Visi dan Misi pondok pesantren Insan Cendekia Boarding SchoolPayakumbuh adalah:

Visi:

"Terwujudnya generasi cerdas, islami, mandiri, dan berprestasi". Indikator Visi:

1) Cerdas emosional, spiritual, intelegensi, sosial dan budaya.

2) Mandiri dalam hal betindak, berpikir kreatif, dan mampu mengatasi permasalahan yang dihadapi serta memiliki rasa percaya diri yang tinggi.

3) Berprestasi dalam bidang akademik, agama, seni dan olahraga. 
4) Berakhlak islami dalam kehidupan sehari-hari

Misi pesantren terpadu Insan Cendekia Payakumbuh:

1) Melakukan pembelajaran yang aktif, inovatif, kreatif, efektif dan menyenangkan.

2) Menerapkan nilai nilai Islam melalui penyelenggaraan sekolah dan proses pembelajaran.

3) Melaksanakan layanan pendidikan secara adil dan memuaskan.

4) Membimbing santri dalam mengembangkan potensi sosial dan budaya.

5) Melakukan penggalian dan pengembangan bakat secara terprogram

6) Melakukan Islamisasi dalam isi dan proses pembelajaran

7) Melakukan pemberdayaan SDM secara berjenjang dan berkesinambungan

8) Melakukan pembimbingan secara komprehensif dengan orientasi terbentuknya akhlak yang mulia.

Pesantren Terpadu Insan Cendekia menyelenggarakan pendidikan berkelanjutan selama 6 (enam) tahun dengan sistem boarding school, yakni 3 tahun di SMP dan 3 tahun SMA.Pesantren ini menyelenggarakan kurikulum terpadu antara Bidang Studi Umum (Kurikulum Depdiknas) dan Bidang Studi Agama (Kurikulum Pesantren) dalam satu sistem yang terpadu secara integral. Kurikulum Pesantren Terpadu Insan Cendekia senantiasa mengikuti dan mengadaptasikan diri dengan perkembangan kurikulum nasional dan menambahnya dengan kurikulum Pesantren Terpadu Insan Cendekia dalam rangka meningkatkan kualitas out-put yang lebih akurat dan memadai dalam konteks kebutuhan masyarakat luas yang variatif.

\section{Motivasi Orang Tua Memilih Pondok Pesantren Insan Cendekia Boarding School Payakumbuh Sebagai Sarana Pendidikan Anak}

Berdasarkan dari hasil wawancara penilis dengan informan, hasil analisis mendapati bahwa terdapat enam tema penting terkait apa sesungguhnya motivasi orang tua memilih ICBS Payakumbuh. Enam tema tersebut dapat terlihat pada gambar 1, berikut. 


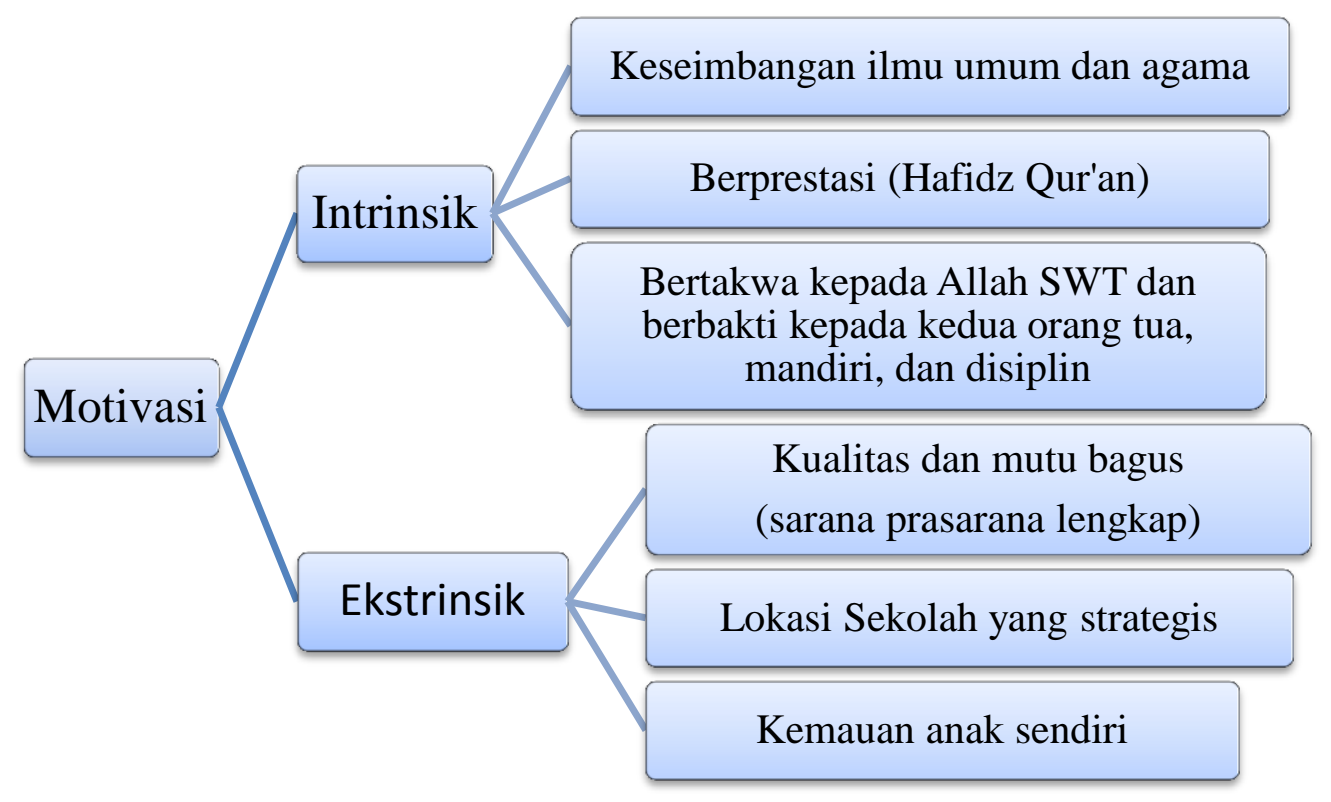

Berdasarkan dari gambar 1 di atas dapat penulis deskripsikan hal-hal yang mendorong atau motivasi orang tua memilih ICBS Payakumbuh yang dikategorikan menjadi motivasi intrinsik dan motivasi ekstrinsik.

Pertama, motivasi intrinsik meliputi keseimbangan Antara Ilmu Pengetahuan Umum dan Agama. Para orang tua memasukkan anak ke ICBS Payakumbuh adalah karena orang tua mempunyai harapan dan juga cita-cita yaitu antara lain sesuai dengan hasil wawancara penulis dengan para orang tua adalah dapat menyeimbangkan ilmu umum dan ilmu agama. Hal ini berangkat dari ayat Al Quran yang menjelaskan tentang perlunya menyeimbangkan ilmu umum dan agama yaitu dalam Q.S Al-Qashash 28: 77.

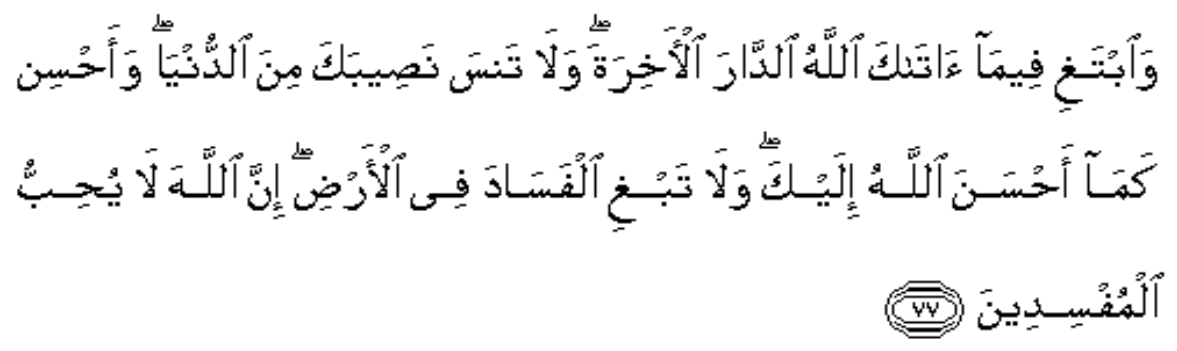

Artinya: "Dan carilah pada apa yang telah dianugerahkan Allah kepadamu (kebahagiaan) negeri akhirat, dan janganlah kamu melupakan bahagiamu dari (kenikmatan) duniawi dan berbuat baiklah (kepada orang lain) sebagaimana Allah telah berbuat baik kepadamu, dan janganlah kamu berbuat kerusakan di (muka) bumi. Sesungguhnya Allah tidak menyukai orang-orang yang berbuat kerusakan”.

Ayat di atas menjelaskan mengenai perlunya manusia menyeimbangkan antara kehidupan dunia dan akhirat. Kehidupan dunia adalah sarana yang akan mengantarkan ke kehidupan akhirat. Kehidupan dunia digunakan untuk beribadah kepada Allah SWT dan dengan adanya keseimbangan antara keduanya, menjalani hidup menjadi lebih tenang. Maka menyeimbangkan ilmu umum dan agama merupakan sebuah perintah dari 
Allah yang dijelaskan di dalam Al Quran dan hal itu menjadi dasar juga bagi orang tua dalam pemilihan sekolah untuk anaknya.

Keseimbangan ini juga diperlukan orang tua untuk membantu mengatasi tantangan dan pengaruh globalisasi. Kekhawatiran terhadap keselamatan anak agar tidak terjerumus ke dalam pergaulan yang tidak baik dan rentan merusak moral dan karakter anak. Sebagaimana yang disampaikan Ibu P dan Ibu Y sebagai berikut.

“...Ante nio anak ante bisa seimbang ilmu umum dan agamanyo..." (Wawancara dengan Ibu P, 25 Maret 2021).

“...Kalau di ICBS Payakumbuh ini yang saya lihat agamanya juga diutamakan dan umumnya juga diperhatikan, jadi seimbang dia. Dapat dua-duanya begitu..." (Wawancara dengan Ibu Y, 26 Maret 2021).

Hal yang sama juga disampaikan oleh ibu $\mathrm{Z}$ mengenai motivasinya memilih ICBS Payakumbuh. "...karena ICBS Payakumbuh itu pesantren, pesantren akan mampu menyeimbangkan ilmu agama dan ilmu umum.." (Wawancara dengan Ibu Z, 27 Maret 2021).

Keseimbangan antara ilmu pengetahuan umum dan ilmu agama anak dapat mencapai cita-cita dikehidupan dunia dengan tidak melupakan kehidupan akhirat. Sebagai contoh anak yang bercita-cita menjadi seorang dokter, kelak jika cita-citanya tercapai maka anak akan menjadi dokter yang berakhlak mulia, berkomitmen kepada Allah SWT dan kepada dirinya dengan menjadi dokter yang mengutamakan peri kemanusiaan dan bisa menjadi dokter yang mengemban amanah dakwah. orang tua memasukkan anak mereka ke ICBS Payakumbuh agar mereka mempunyai bekal tidak hanya ilmu pengetahuan umum saja tetapi juga ilmu pengetahuan agama. Sebagaimana yang disampaikan Ibu F berikut; "Anak ibu punya cita-cita jadi dokter, karena ibu lihat ICBS Payakumbuh dapat menyeimbangkan ilmu umum dan agama, ibu masukkanlah anak ibu kesana dengan harapan jika kelak cita-citanya tecapai dia bisa menjadi dokter yang berakhlak mulia, seorang dokter yang juga memahami ilmu agama..." (Wawancara Ibu F, 26 Maret 2021).

Motivasi selanjutnya meliputi keinginan Agar Anak Menjadi Hafidz dan Hafidzah. Orang tua memasukkan anak mereka ke ICBS Payakumbuh karena berkeinginan agar anak menjadi seorang hafidz dan hafidzah yang memahami dan mencintai Al Quran dan Sunnah. Terdapat banyak faedah besar bagi para orang tua yang mengarahkan anak untuk mempelajari, menghafal, dan mengamalkan isi Al Quran salah satunya terdapat dalam Hadits Nabi Muhammad SAW. Dari Buraidah radhiyallahu'anhu, Nabi shallallahu'alaihi wa sallam bersabda yang artinya "Siapa yang menghafal Al Quran, mengkajinya dan mengamalkannya, maka Allah akan memberikan mahkota bagi kedua orang tuanya dari cahaya yang terangnya seperti matahari. Dan kedua orang tuanya akan diberi dua pakaian yang tidak bisa dinilai dengan dunia." (HR. Hakim 1/756 dan dihasankan al-Abani).

Mereka ingin anak mereka menjadi seorang penghafal Al Quran untuk menjadi penghuni surga dan bisa membantu orang tuanya masuk surga, karena orang tua menyadari dosa-dosa yang mereka miliki tidak bisa menjamin masuk surga dan orang tua berharap dengan anaknya menjadi penghafal Al Quran dapat menarik mereka masuk surga. Sebagaimana yang dipaparkan oleh Ibu R berikut; “...saya ingin anak saya jadi 
penghafal Al Quran yang baik dan menjadi insan yang lebih baik lagi..." (Wawancara dengan Ibu R, 27 Maret 2021).

Keinginan yang sama juga disampaikan oleh Ibu $\mathrm{T}$ dan Ibu $\mathrm{Y}$ terhadap anaknya. “...ibu ingin anak ibu menjadi penghafal Al Quran dan dengan sekolah di ICBS Payakumbuh dapat meningkatkan hafalannya..." (Wawancara dengan Ibu T, 20 februari 2021). "...bagi ibu bagaimana anak ibu bisa memahami agama dan menjadi hafidz Al Quran...” (Wawancara dengan Ibu Y, 25 Maret 2021).

Motivasi yang lain adalah keinginan agar anak yang bertakwa kepada Allah SWT, mandiri, disiplin dan berbakti kepada kedua orang tua. Orang tua berharap anaknya menjadi anak yang bertaqwa kepada Allah SWT, mempunyai kemandirian, menjadi lebih disiplin dan berbakti kepada kedua orang tuanya. Sebagaimana yang disampaikan oleh Ibu R tentang keinginannya. “...Ibu harap dengan dipondokkan anak ibu bisa bertakwa kepada Allah, berbakti kepada orang tua dan ibu ingin anak ibu mandiri dan mempunyai kedisiplinan dalam hidupnya..." (Wawancara dengan Ibu R, 28 Maret 2021).

Hal yang sama juga disampaikan oleh Ibu Y mengenai alasan memasukkan anaknya ke ICBS Payakumbuh. “...Perubahan dari anak saya juga sudah jauh berubah, sekarang dia lebih mandiri dan disiplin dalam mengerjakan sesuatu..."(Wawancara dengan Ibu Y, 28 Maret 2021).

Ibu $\mathrm{R}$ juga menyampaikan hal yang serupa tentang alasan memasukkan anak ke ICBS Payakumbuh. “...Ibu berharap agar anak ibu menjadi anak yang sholehah dan berakhlak mulia, ibu lihat perubahan dari anak ibu dia lebih mandiri, sudah rajin shalat dan puasa sunah. Lebih disiplin dari sebelumnya..." (Wawancara dengan Ibu R, 27 Maret 2021).

Kepala Sekolah SMP IT ICBS Payakumbuh mengatakan terkait dengan penyeimbangan ilmu umum dan ilmu agama yang ada di ICBS Payakumbuh. “...Kita hari ini berbeda insyaaAllah, yang kita lakukan justru keseimbangan (tawwazuun) antara umum dan agama. Keseimbangan antara umum dan agama itu kita masukkan dalam muatan kurikulum kita kemudian untuk agamanya memang keseharian anakanak kita, kita isi dengan berbagai kegiatan keagamaan atau kegiatan kepesantrenan dalam rangka membekali mereka dengan wawasan keagamaan, membekali mereka dengan ilmu-ilmu agama yang InsyaaAllah akan menjadikan mereka semakin menyeimbangkan antara dunia dengan akhirat, antara ilmu umum dengan ilmu agama”. (Wawancara dengan Kepala Sekolah SMP IT ICBS Payakumbuh, 5 Maret 2021).

Berdasarkan dari hasil wawancara penulis dengan orang tua, motivasi intrinsik para orang tua memilih ICBS Payakumbuh sebagai sarana pendidikan anak adalah karena orang tua melihat pondok pesantren ini lebih bagus dalam hal menyeimbangkan antara ilmu umum dan ilmu agama, keinginan agar anak menjadi seorang hafidzh dan hafidzah yang memahami dan mencintai Al Quran dan Sunnah, kemudian juga orang tua berharap anaknya mempunyai kemandirian, menjadi lebih disiplin dan menjadi anak yang bertaqwa kepada Allah SWT dan berbakti kepada kedua orang tuanya.

Kedua, motivasi ekstrinsik dimana ICBS Payakumbuh dipandang oleh orang tua memiliki kualitas yang bagus. Orang tua memilih ICBS Payakumbuh karena dipandang 
mempunyai kualitas dan mutu yang bagus. Hal ini dilihat oleh orang tua dari promosi yang dilakukan oleh ICBS Payakumbuh. Orang tua mencari informasi di media sosial dan melihat dari alumni yang telah menyelesaikan pendidikannya di ICBS Payakumbuh telah berhasil melanjutkan pendidikan tingginya baik di universitas ternama di Indonesia maupun diluar negeri. Sebagaimana hasil wawancara penulis dengan Ibu Y."..Saya memasukkan anak di ICBS Payakumbuh karena saya merasa mutu dam kualitasnya bagus dan saya merasa disiplin disana juga bagus dilihat dari perubahan yang terjadi pada anak saya.." (Wawancara dengan Ibu Y, 16 Maret 2021).

Hal yang hampir sama juga disampaikan oleh Ibu SM tentang alasannya memasukkan anak ke ICBS Payakumbuh. “...Kami merasa ICBS Payakumbuh itu bagus dan anak kami juga tertarik dengan ICBS Payakumbuh, bagi saya yang penting adalah kualitas sekolah yang baik dan mampu mendidik anak saya menjadi lebih baik..." (Wawancara dengan Ibu SM, 26 Maret 2021). Disamping itu Ibu Y menyatakan alasannya memilih ICBS Payakumbuh. “...ibu cari-cari informasi tentang ICBS Payakumbuh ini dan akhirnya membuat ibu yakin menyekolahkan anak di ICBS Payakumbuh karena ibu melihat kualitas yang dimiliki ICBS Payakumbuh sangat baik..." (Wawancara dengan Ibu Y, 26 Maret 2021).

Selain dari pondok pesantren Insan Cendekia Boarding School Payakumbuh dilihat oleh orang tua memiliki mutu dan kualitas yang bagus, motivasi lainnya adalah lokasi sekolah yang terletak di lingkungan yang memiliki cuaca tidak terlalu panas dan juga tidak terlalu dingin atau bisa disebut mempunyai lingkungan yang asri dengan bangunan sekolah dan sarana prasana yang bagus, rapi kemudian juga jauh dari polusi udara yang ada dikota-kota besar. Seperti yang dipaparkan oleh ibu D. “...Ibu melihat lokasi sekolah atau lingkungannya baik ya atau cocoklah untuk menghafal Al Quran, nyaman lingkungannya, sejuk juga dan sarana dan prasarananya ibu rasa sudah lengkap dan yang penting anak ibu nyaman bersekolah disana..." (Wawancara dengan Ibu D, 27 Maret 2021).

Berdasarkan berbagai banyaknya pertimbangan dalam memilih lembaga pendidikan untuk anak, lokasi sekolah juga tidak luput dari pertimbangan para orang tua. Orang tua tentunya ingin anak mereka ketika masuk kesuatu lembaga pendidikan, dapat merasakan kenyamanan disana baik itu nyaman dalam suasana, cuaca dan lingkungan. Sebagaimana hasil wawancara dengan Ibu T dan Ibu O. “...Lokasinya strategis lah, lingkungannya nyaman, sejuk ditambah lagi dengan bangunan sekolahnya yang bagus, apalagi yang dikawasan Harau bangunan sekolah yang bagus dan rapi kemudian juga jauh dari polusi udara...” (Wawancara dengan Ibu T, 20 Februari 2021). "Dilihat dari lokasi sekolahnya ya ibu melihatnya bagus ya, lingkungannya sejuk, asri, nyaman disana...” (Waancara dengan Ibu O, 26 Maret 2021).

Kepala Sekolah SMP IT Insan Cendekia Boarding School Payakumbuh juga memaparkan dalam wawancara tanggal 5 Maret 2021 mengenai mengapa pondok pesantren Insan Cendekia Boarding School Payakumbuh ini banyak diminati dan keunggulan yang dimiliki oleh pondok pesantren Insan Cendekia Boarding School Payakumbuh. "ICBS Payakumbuh diminati banyak orang itu sebenarnya lebih karena faktor-faktor yang memang penggabungan antara manajemen serta mutu dan kurikulum yang terintegrasi antara pendidikan Islam dengan umum. Kemudian selain 
hal itu tentunya tidak kalah penting adalah manajemen pengelolaan sekolah yang memang sangat dilakukan dengan profesional seperti halnya manajemen promosi yang biasanya oleh sekolah-sekolah biasa hanya dilakukan sekedarnya saja namun bagi kita promosi dilakukan memang betul-betul serius dan berkesinambungan. Serius dalam arti memang kita melaksanakan promosi sekolah tidak hanya menjelang dibukanya pendaftaran peserta didik baru tetapi juga sepanjang tahun kegiatan pembelajaran berjalan. Apapun aktivitas kita kita jadikan ajang promosi untuk memperkenalkan sekolah kepada khalayak ramai. Selain itu juga tentunya secara mutu ataupun kurikulum kita alhamdulillah sudah menunjukkan hasil yang cukup memuaskan diantaranya prestasi-prestasi anak kita yang memang tidak hanya ditingkat daerah, provinsi bahkan juga alhamdulillah sampai ke tingkat nasional. Begitu juga dilevel SMA anak-anak kita sudah berhasil menempuh pendidikan yang lebih tinggi ketempattempat yang bagus seperti ke timur tengah atau diluar negeri"

Kepala sekolah juga menambahkan mengenai lokasi sekolah dan sarana prasarana yang dimiliki oleh Pondok Pesantren Insan Cendekia Boarding School Payakumbuh. "ICBS Payakumbuh diuntungkan pada lokasi sekolah yang membuat orang tertarik yang lebih relatif lebih aman dan menyenangkan dengan suasana yang nyaman barangkali terlihat atau dirasakan oleh orang tua untuk ditempati atau dititipkan anak-anaknya. Sarana-sarana dalam menunjang keterlaksanaan pendidikan disekolah kita alhamdulillah tentunya secara utama ataupun yang paling primer adalah kebutuhan kelas atau sarana kelas kemudian sarana asrama semuanya itu alhamdulillah terlengkapi dengan baik. Di sekolah maupun di asrama kebutuhan anakanak mulai dari proses pembelajaran kurikulum hingga co kurikulumnya seperti ekstrakurikuler atau pembelajaran kepresantrenan keasramaan alhamdulillah semиa terlengkapi dengan sarana prasarana yang baik”.

Hal terpenting dan yang utama adalah adanya kemauan anak itu sendiri. Tidak ada paksaan dari orang tua untuk anak dalam pemilihan sekolah di ICBS Payakumbuh. Sebagaimana yang dipaparkan Ibu Y dan Ibu S. “...Anak saya masuk ke ICBS Payakumbuh karena memang anaknya yang mau bersekolah disana..." (Wawancara dengan Ibu Y, 26 Maret 2021). “...Kami lihat ICBS Payakumbuh bagus dan anak kami suka dengan sekolahnya maka kami masukkanlah dia kesana. Tidak ada paksaan dari kami sebagai orang tua anak kami mau sekolah dimana, yang penting kalau dia mau sekolah di ICBS Payakumbuh kami turuti..." (Wawancara dengan Ibu S, 27 Maret 2021).

Motivasi memegang peranan cukup penting bagi keberlangsungan dan keberhasilan anak dalam belajar. Apabila orang tua memberikan motivasi yang baik kepada anak, maka dalam diri anak juga akan timbul dorongan atau keinginan untuk belajar menjadi lebih baik. Motivasi orang tua juga merupakan pemacu semangat anak untuk berprestasi dan membanggakan kedua orang tuanya dengan prestasi yang mereka punya. Untuk dapat menjadi anak yang berprestasi, tentunya perlu adanya pengarahan serta pendidikan dari orang tua dan tidak kalah penting pemilihan sekolah juga menjadi faktor keberhasilan anak dalam belajar. Dengan pemilihan sekolah yang baik untuk proses belajar anak maka anak lebih berkesempatan mendapatkan fasilitas belajar yang 
lebih baik pula. Kemudian sarana, prasarana dan lingkungan sekolah bersirkulasi udara yang baik akan membantu kelancaran proses belajar anak.

Uraian orang tua di atas menjelaskan berbagai alasan mengapa mereka memilih dan mengarahkan pendidikan bagi anak mereka. Alasan-alasan tersebut bermula pada sikap untuk mengantisipasi banyaknya kerusakan moral yang dialami generasi bangsa, khususnya generasi muda dan juga semata-mata untuk mencerdaskan anak-anak mereka, membekali dengan ilmu pengetahuan umum serta nilai-nilai agama untuk dijadikan landasan hidup bagi anak dimasa datang.

Kesimpulannya motivasi orang tua memilih ICBS Payakumbuh sebagai sarana pendidikan anak adalah karena semata-mata untuk mencerdaskan anak-anak mereka dan membekali anak-anak mereka dengan ilmu pengetahuan serta nilai-nilai agama dan menjadi langkah awal dalam meletakan pendidikan dasar dan nilai-nilai keagamaan untuk dijadikan landasan hidup bagi anak dimasa yang akan datang.

\section{Simpulan}

Berdasarkan pemaparan di atas dapat disimpulkan bahwa motivasi orang tua memilih pondok pesantren Insan Cendekia Boarding School Payakumbuh adalah sebagai berikut:Motivasi intrinsik merupakan dorongan atau kemauan yang kuat dalam diri individu sedangkan motivasi ekstrinsik merupakan motivasi yang berasal dari luar diri individu. Hasil penelitian menjelaskan motivasi intrinsik orang tua memilih pondok pesantren Insan Cendekia Boarding School Payakumbuh adalah karena ICBS Payakumbuh dipandang bisa menyeimbangkan antara ilmu umum dan juga ilmu agama bagi para peserta didiknya, keinginan agar anak menjadi seorang hafidzh dan hafidzah yang memahami dan mencintai Al Quran dan Sunnah, dan orang tua berharap anaknya mempunyai kemandirian, menjadi lebih disiplin dan menjadi anak yang bertakwa kepada Allah SWT dan berbakti kepada kedua orang tuanya.

Motivasi ekstrinsik orang tua memilih pondok pesantren Insan Cendekia Boarding School Payakumbuh adalah karena keinginan anak untuk sekolah di pondok ICBS Payakumbuh, orang tua melihat ICBS Payakumbuh mempunyai kualitas dan mutu yang bagus melihat sarana dan prasarana yang dimiliki oleh pondok pesantren ini lengkap dan memuaskan, serta lokasi sekolah yang terletak dilingkungan yang memiliki cuaca tidak terlalu panas dan juga tidak terlalu dingin.

\section{Referensi}

Aprianto, R. A. (2019). Motivasi Orang Tua Menyekolahkan Anak Ke Pondok Pesantren. JOM FISIP, 6, 1-

15.https://jom.unri.ac.id/index.php/JOMFSIP/article/download/25692/24889.

Hendriani, W \& Nadya. (2018). Mengapa Memilih Sekolah Internasional? (Studi Kasus Pengambilan Keputusan Orang Tua Dalam Pemilihan Sekolah Untuk Anak. Jurnal Ilmiah Psikologi, $\quad 9, \quad$ 1631.http://journal.paramadina.ac.id/index.php/inquiry/article/view/221. 
Jailani, M. S. (2014). Teori Pendidikan Keluarga Dan Tanggung Jawab Oang Tua Dalam Pendidikan Anak Usia Dini. Nadwa Jurnal Pendidikan Islam, 8, 245260.https://journal.walisongo.ac.id/index.php/Nadwa/article/download/580/527.

Marzuki \&Maskurin, A. (2019). Motif Orang Tua Santri Di Pondok Pesantren HM Lirboyo. $\quad 30, \quad$ 166-181. https://ejournal.iaitribakti.ac.id/index.php/tribakti/article/view/667.

Mahu, S. Abdurrahman, M. Nufus, H. (2019). Motivasi Orang Tua Menyekolahkan Anaknya Di Pesantren Sebagai Sarana Pembinaan Akhlak. kuttab, 1, 1-13.

Nurniswah. (2017). Kota Bengkulu "Identifikasi Faktor Penentu Pemilihan Sekolah Agama (Studi Kasus Pada Orang Tua Di Kelurahan Kandang Mas. Manhaj, 5, 18.

Saputra, A. (2015). Motivasi Orang Tua Menyekolahkan Anak Ke Sekolah Islam Terpadu. JOM FISIP, 2, 116.https://jom.unri.ac.id/index.php/JOMFSIP/article/view/6795.

Septianti, D \&Frastuti, M. (2019). Pengaruh Penggunaan Media Berbasis Internet, Motivasi Intrinsik Dan Motivasi Ekstrinsik Terhadap Minat Berwirausaha Online Mahasiswa Universitas Tridinanti Palembang. JURNAL ILMIAH EKONOMI $\begin{array}{llll}\text { GLOBAL MASA } & \text { KINI, }\end{array}$ 138. http://ejournal.uigm.ac.id/index.php/EGMK/article/view/871.

Sugiyono. (2012). Metode Penelitian Kuantitatif Kualitatif dan R\&D. Bandung: Alfabeta.

Sutrisno, E. (2009). Manajemen Sumber Daya Manusia. Jakarta: Kencana.

Syafe'i, I. (2017). Pondok Pesantren: Lembaga Pendidikan Pembentukan Karakter. AlTadzkiyyah Jurnal Pendidikan Islam, 8, 61-82.

Winardi, J. (2001). Motivasi \& Pemotivasian dalam Manajemen. Jakarta: PT RajaGrafindo Persada.

Zuhry, M. S. (2011). Budaya Pesantren Dan Pendidikan Karakter Pada Pondok Pesantren Salaf. Walisongo, 19, 287-310. 